\title{
Influence of Rhizobacteria Inoculant Application Methods and Phosphate Fertilizer Rates on Dry Matter Accumulation, Yield of Bambara Groundnut [Vigna subterranea (L.) Verdc] and Soil Total Nitrogen Content in a Degraded Ultisol in Southeast Nigeria
}

\section{Ikenganyia EE, Anikwe MAN and Ngwu OE}

Department of Agronomy and Ecological Management, Faculty of Agriculture and Natural Resources Management, Enugu State University of Science and Technology, Agbani, Enugu State, Nigeria

\begin{abstract}
Bacterial inoculants contribute to increased agronomic efficiency in the rhizosphere via its effects on biological nitrogen fixation, phosphate solubilization and other plant growth promotion (PGP) traits. This study evaluates the influence of rhizobacteria inoculant application methods and phosphate fertilizer rates on dry matter accumulation, nodulation, yield of Bambara groundnut [Vigna subterranea (L.) Verdc] and post-harvest soil total nitrogen content in a Typic Paleudult in Southeast Nigeria ( $6^{\circ} 29^{\prime} \mathrm{N} ; 7^{\circ} 54^{\prime} \mathrm{E}$ ). Field trials were conducted in 2015 and 2016 cropping seasons in a $2 \times 4$ factorial in a randomized complete block design with three replications. The treatments were four rates of single super phosphate fertilizer $\left(0 \mathrm{~kg} \mathrm{Pha}^{-1}, 25 \mathrm{~kg} \mathrm{Pha}^{-1}, 50 \mathrm{~kg} \mathrm{Pha}^{-1}\right.$ and $\left.75 \mathrm{~kg} \mathrm{Pha}^{-1}\right)$ and two rhizobacteria inoculant application methods (seed applied method and soil applied method). The results from the study showed that soil applied rhizobacteria inoculant increased leaf, stem and root dry weight of Bambara groundnut significantly $(P<0.05)$ by between $19 \%-25 \%$ when compared with seed applied rhizobacteria inoculants. Similarly, soil applied rhizobacteria inoculant increased number of root nodules, fresh pods of Bambara groundnut and soil total nitrogen content at 90 days after planting (DAP) significantly $(P<0.05)$ by $29 \%, 22 \%$ and $19 \%$ respectively when compared with seed applied rhizobacteria inoculants. Soils fertilized with $75 \mathrm{~kg} \mathrm{P}^{-1} \mathrm{~h}^{-1}$ produced the highest dry matter (above and below) yield of Bambara groundnut (97.37 g plant) and this was significantly higher than when $\mathrm{P}$ was applied at $0 \mathrm{~kg} \mathrm{P}^{-1}, 25 \mathrm{~kg} \mathrm{P}^{-1}$ and $50 \mathrm{~kg} \mathrm{P}^{-1}$ by $54 \%, 32 \%$ and $15 \%$ respectively for the two cropping seasons. The interaction effect showed that soils fertilized with $75 \mathrm{~kg} \mathrm{P}^{-1}$ combined with soil application method of rhizobacteria inoculation produced the highest fresh pod yield of Bambara groundnut (178.4 g plant) and postharvest soil total $\mathrm{N}$ content $(0.29 \%)$ and this was significantly higher in plots without $\mathrm{P}$ in seed applied rhizobacteria plots by $52 \%$ and $88 \%$ for the two cropping seasons. The results of our study showed that the inoculation method plays an important role in determining the success of microbial inoculation. Soil inoculation rather than seed application of exogenous rhizobacteria and up to $75 \mathrm{Kg} \mathrm{P}^{-1}$ is recommended that for optimal dry matter yield and increment in postharvest soil total nitrogen content for cultivation of Bambara groundnut in degraded Ultisols and soils with similar edaphic conditions.
\end{abstract}

Keywords: Bambara groundnut; Rhizobacteria; Dry matter accumulation; Phosphate fertilizer

\section{Introduction}

Bambara groundnut is an African indigenous legume that has been cultivated for centuries in sub-Saharan Africa, mainly the semiarid regions, and has in the past contributed to food security [1-4]. Bambara plant makes little demand on soil nutrients, thus is useful for climate change adaptable agriculture. Access to the nitrogen allows the plants to produce leaves fortified with nitrogen that can be recycled throughout the plant which in turn yields nitrogen-rich seeds [5]. Through symbiotic relationships with rhizobacteria, it fixes atmospheric nitrogen to the soil, thereby benefitting crop rotations and intercropping systems $[6,7]$. Bambara groundnut has been reported to fix up to $28.42 \mathrm{~kg} \mathrm{~N} \mathrm{ha}^{-1}$ in the Sudano-Sahelian zone of Nigeria [8]. Bambara nuts contain $63 \%$ carbohydrates, $19 \%$ protein and $6.5 \%$ oil $[9,10]$ characterized its micro nutrient content per $100 \mathrm{mg}$ as calcium ( $95.5 \mathrm{mg}$ to $99.0 \mathrm{mg}$ ), iron ( $5.1 \mathrm{mg}$ to $9.0 \mathrm{mg}$ ), potassium (11.45 mg to $14.36 \mathrm{mg}$ ) and sodium ( $2.9 \mathrm{mg}$ to $10.6 \mathrm{mg}$ ). Its high protein content confers advantage in alleviating nutritional disorders in both humans and animals [11].

In Enugu area southeast Nigeria, preliminary investigation showed that the soils are strongly acidic. The organic carbon, nitrogen and available phosphorus were very low [12] considering bench mark for tropical soils. The results depict soils that are poor, degraded and of low fertility status. This condition is caused by over exploitation, nutrient volatilization, erosion or leaching [13]. The agronomic practices such as plant spacing and phosphate fertilizer requirements and inoculation technologies for the improvement of productivity of Bambara groundnut have not yet been fully determined in southeast Nigeria.

It is, therefore, considered necessary to introduce the use of plant growth promoting rhizobacteria inoculant as an ameliorant in order to reclaim and improve the fertility and productivity of

*Corresponding author: Ikenganyia EE, Department of Agronomy and Ecological Management, Faculty of Agriculture and Natural Resources Management, Enugu State University of Science and Technology, Agbani, Enugu State, Nigeria, Tel: +234 (0) 811-369-3824; E-mail: eejike43@yahoo.com

Received August 16, 2017; Accepted September 01, 2017; Published September 08, 2017

Citation: Ikenganyia EE, Anikwe MAN, Ngwu OE (2017) Influence of Rhizobacteria Inoculant Application Methods and Phosphate Fertilizer Rates on Dry Matter Accumulation, Yield of Bambara Groundnut [Vigna subterranea (L.) Verdc] and Soil Total Nitrogen Content in a Degraded Ultisol in Southeast Nigeria. Agrotechnology 6: 165. doi: 10.4172/2168-9881.1000165

Copyright: ( 2017 Ikenganyia EE, et al. This is an open-access article distributed under the terms of the Creative Commons Attribution License, which permits unrestricted use, distribution, and reproduction in any medium, provided the original author and source are credited. 
Citation: Ikenganyia EE, Anikwe MAN, Ngwu OE (2017) Influence of Rhizobacteria Inoculant Application Methods and Phosphate Fertilizer Rates on Dry Matter Accumulation, Yield of Bambara Groundnut [Vigna subterranea (L.) Verdc] and Soil Total Nitrogen Content in a Degraded Ultisol in Southeast Nigeria. Agrotechnology 6: 165. doi: 10.4172/2168-9881.1000165

Page 2 of 7

the soil. As side the biological nitrogen fixation potentials of plant growth promoting bacteria such as Allorhizobium, Bradyrhizobium, Mesorhizobium and Rhizobium, [14], these bacteria are also helpful in a variety of mechanisms that involve soil structure formation, decomposition of organic matter, recycling of essential elements, solubilization of mineral nutrients, producing numerous plant growth regulators, degrading organic pollutants, stimulation of root growth crucial for soil fertility, bio-control of soil and seed borne plant pathogens and in promoting changes in vegetation [15]. Plant growth promoting rhizobacteria can reduce chemical fertilizers use and it is economically and environmentally beneficial for lowering production cost. It is suitable for sustainable crop production and soil fertility restoration [16].

Application of beneficial microorganisms to seeds or directly in the soil are mechanisms for placement of microbial inocula into soil where they will be well positioned to colonize seedling roots and protect against soil-borne diseases and pests. However, despite the long history of inoculation of legume seeds with Rhizobia spp. and clear laboratory demonstration of the ability of a wide range of other beneficial microorganisms to improve crop performance, there are still very few commercially available microbial seed or soil inoculants [17]. Seed and soil inoculation techniques used for research purposes are often not feasible at a commercial scale and there are significant technical challenges in maintaining viable microbial inocula on seed throughout commercial seed treatment processes and storage. Further research is needed before the benefits of a wide range of environmentally sensitive potential seed or soil inoculants can be captured for use in agriculture, ecosystem restoration and bioremediation [17].

Legumes are phosphorus loving plants. They require phosphorus for growth, nodulation and seed development, and most especially in nitrogen fixation which is an energy driving process [18]. Investigations by [18], revealed that the highest application rate of single super phosphate fertilizer $\left(70 \mathrm{~kg} \mathrm{P} \mathrm{ha}^{-1}\right)$ increased the number of leaves per plant, number of branches per plant, plant height, leaf area index and weight of pod after harvest of Mucuna flagellipes in a degraded acid tropical Ultisol. Careful application of phosphorus fertilizer to legumes must be geared towards enhancing not only their growth and yield, but also nitrogen fixation. In Nigeria, legumes rarely receive any form of mineral phosphorus fertilizer. They, therefore, rely entirely on the natural available soil phosphorus and other nutrients for nitrogen fixation and growth and this has resulted in lower yield and low nitrogen fixation by these legumes [18].

The general objective of this study is to determine the influence of rhizobacteria inoculant application methods and phosphate fertilizer rates on dry matter accumulation, nodulation and yield of Bambara groundnut [Vigna subterranea (L.) Verdc] and post-harvest soil total nitrogen content in a Typic Paleudult in Southeast Nigeria.

The specific objectives are:

To determine the effects of soil-and seed applied rhizobacteria inoculant application methods and phosphate fertilizer rates $(0 \mathrm{~kg} \mathrm{P} \mathrm{ha-}$ ${ }^{1}, 25 \mathrm{~kg} \mathrm{Pha}^{-1}, 50 \mathrm{~kg} \mathrm{Pha}^{-1}$ and $\left.75 \mathrm{~kg} \mathrm{P} \mathrm{ha}^{-1}\right)$ on dry matter accumulation, yield of Bambara groundnut [Vigna subterranea (L.) Verdc.] and soil total nitrogen content.

To determine the relationship between the number of nodules, fresh pod weight, soil total nitrogen content and phosphate fertilizer rates in Bambara groundnut plots.

\section{Materials and Methods}

\section{Soil characterization}

This experiment was carried out in 2015 and 2016 planting season respectively at the Teaching and Research Farm of the Faculty of Agriculture and Natural Resources Management, Enugu State University of Science and Technology, Nigeria $\left(06^{\otimes} 52^{\prime} \mathrm{N}, 07^{\otimes} 15^{\prime} \mathrm{E}\right.$ and elevation $450 \mathrm{~m}$ above sea level) [19]. The area has an annual rainfall which ranges from $1700 \mathrm{~mm}$ to $2010 \mathrm{~mm}$. The rainfall pattern is bimodal and is between April and October, and the dry season is between November and March. The soil's textural class is sandy loam with an isohyperthermic raulic conductivity were $41 \%$ and $21.72 \mathrm{~cm}$ $\mathrm{hr}^{-1}$ respectively.

\section{Field methods}

soil temperature regime [19] and is classified as Typic Paleudult [20]. The pre-planting percentage organic carbon, nitrogen and available $\mathrm{P}$ were $0.65 \%, 0.038 \%$ and $7.91 \% \mathrm{cmol} \mathrm{kg}^{-1}$ respectively. The soil $\mathrm{pH}$ in $\mathrm{KCl}$ was 5.4, CEC 8.10, $\mathrm{Mg} 0.72, \mathrm{~K} 0.17, \mathrm{Na} \mathrm{0.90}$, and $\mathrm{Al} 3.24$ $\mathrm{cmol} \mathrm{kg}{ }^{-1}$. The soil dry bulk density was $1.52 \mathrm{Mg} \mathrm{m}^{-3}$.

The experiment was a $2 \times 4$ factorial trial in a randomized complete block design with three replications. The treatments were four rates of single super phosphate fertilizer $\left(0 \mathrm{~kg} \mathrm{P} \mathrm{ha}{ }^{-1}, 25 \mathrm{~kg} \mathrm{P} \mathrm{ha}^{-1}, 50 \mathrm{~kg} \mathrm{P} \mathrm{ha}^{-1}\right.$ and $\left.75 \mathrm{~kg} \mathrm{P} \mathrm{ha}^{-1}\right)$ and two rhizobacteria inoculant application methods (seed applied method and soil applied method). Healthy Bambara groundnut seeds (Cultivar TVSU 1061 from IITA Ibadan Nigeria) were selected, washed with $95 \%$ ethanol, surface sterilized with $3.5 \%$ sodium hypochlorite (commercial bleach) and then rinsed with distilled water before inoculation.

Preparation of inoculant slurry (Figure 1a): Materials: $500 \mathrm{ml}$ of bottled water can, wooden stirring spoon plastic basin, 3 liter capacity Rhizobacteria inoculant (Nodumax legume inoculant manufactured by IITA business incubation platform, Ibadan Nigeria), Bambara groundnut seeds, white paper.

\section{Seed inoculation procedure (Figure 1b)}

The enclosed gum Arabic (sticker) inside the sachet of Nodumax inoculant was dissolved into $300 \mathrm{ml}$ of warm water to form a slurry, 15 $\mathrm{kg}$ of Bambara groundnut seeds were poured into a basin, the slurry formed was added to the seeds and mixed uniformly, $100 \mathrm{~g}$ of nodumax inoculant was added uniformly to the seeds and covered for $10 \mathrm{~min}$ to avoid direct sunlight. The inoculated Bambara groundnut seeds (Figure 1c) were planted into a moist seed bed.

\section{Soil inoculation procedure (Figure 2a)}

Planting holes were made to a depth of $10 \mathrm{~cm}$ using a plant spacing of $20 \mathrm{~cm} \times 45 \mathrm{~cm}$ (intra $\times$ inter row spacing) on each seed bed. Inside the planting holes, ten grams of rhizobacteria inoculants were measured out and placed into each of the planting hole then the un-inoculated Bambara groundnut seeds (Figure $2 \mathrm{~b}$ ) and covered with the soil.

\section{Field operations}

A total land area measuring $190 \mathrm{~m}^{2}(22 \mathrm{~m} \times 10 \mathrm{~m})$ was used for the experiment. The land was divided into three blocks (columns: northsouth direction), and each was sub-divided into eight plots (rows: east-west direction) making a total of twenty-four plots. Plots (beds) measuring $2 \mathrm{~m} \times 2 \mathrm{~m}\left(4 \mathrm{~m}^{2}\right)$ was separated by $1 \mathrm{~m} \times 1 \mathrm{~m}$ pathway between and in between plots. The Bambara seeds were planted at $10 \mathrm{~cm}$ depth using $0.20 \mathrm{~m} \times 0.45 \mathrm{~m}$ planting distance at one seed per 
Citation: Ikenganyia EE, Anikwe MAN, Ngwu OE (2017) Influence of Rhizobacteria Inoculant Application Methods and Phosphate Fertilizer Rates on Dry Matter Accumulation, Yield of Bambara Groundnut [Vigna subterranea (L.) Verdc] and Soil Total Nitrogen Content in a Degraded Ultisol in Southeast Nigeria. Agrotechnology 6: 165. doi: 10.4172/2168-9881.1000165

Page 3 of 7

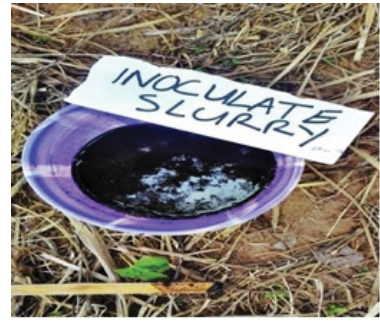

(1a) Inoculant slurry

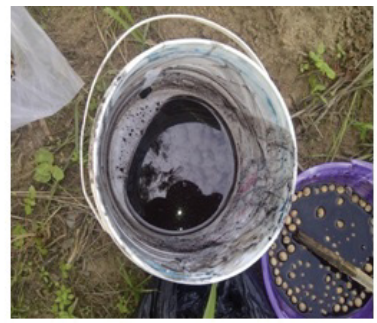

(1b) Seed inoculation

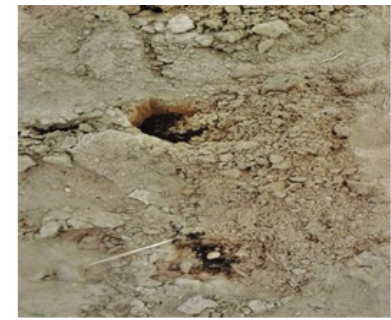

(1c) Soil inoculation

Figure 1: Preparation of inoculant slurry, seed inoculation and soil inoculation.

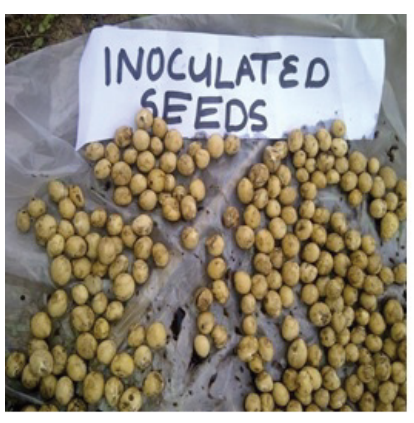

(2a) Rhizobacteria inoculated seeds

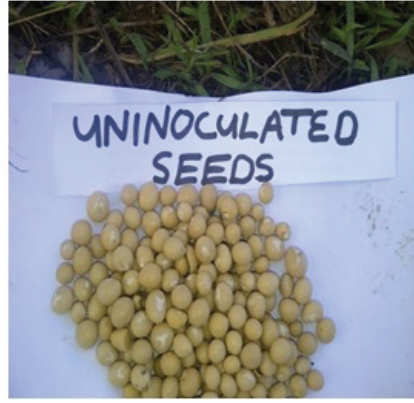

(2b) Uninoculated seeds

Figure 2: Rhizobacteria inoculated and uninoculated Bambara groundnut seeds [Vigna subterranea (L.) Verdc.].

hole giving a plant population of 111,111 plants hectare ${ }^{-1}$. Lost stands were replaced. Prophylactic application of $15 \mathrm{ml}$ of Karate (Pyrethroid insecticide) in five liters of water was applied at one week after planting and at four, six and eight weeks after planting to avert pest incidence. Three plants at the center rows were sampled during data collection. One weeding regime was carried out manually using small hoe at 21 DAP. Subsequently, rouging was employed to reduce weed competition in each of the seasons.

\section{Observation and data collection}

Number of nodules per plant was obtained at 60 DAP whereas number of fresh pods were determined at harvest (120 DAP). In determining the number of nodules and fresh pods, a spade was used to carefully scoop out the soil containing the plant roots. The soil with the roots was then immersed in a basin of water to remove the soil, the roots were recovered and the nodules counted manually. The number of fresh pods per plant at harvest was manually counted. Fresh pods per plant were weighed using electronic weighing balance. Sampled plants were separated into leaves, stems and roots and put in a paper envelope and oven dried at $80^{\circ} \mathrm{Celsius}$ to a constant weight for three days for the dry matter determination of leaf, stem and root at harvest.

\section{Laboratory methods}

Soil samples were collected from the top soil at a depth of 0 to 15 $\mathrm{cm}$ before planting and at harvest. Three representative soil samples were randomly collected per plot and bulked to form a composite soil sample for each plot. A total of twenty-four composite soil samples were collected. Samples were air dried ground and passed through a sieve of $2 \mathrm{~mm}$ standard mesh size. The soil $\mathrm{pH}$ was determined with a $\mathrm{pH}$ meter using 1:2.5 soil to water ratio and 1: 2.5 soil to $0.1 \mathrm{~N} \mathrm{KCl}$ (potassium chloride) suspension [21,22]. Soil organic carbon was determined using the Walkley and Black wet digestion method. Soil organic matter content was obtained by multiplying the value of organic carbon by
1.724 (Van Bemmeler factor). Total nitrogen was determined by MicroKjeldahl procedure before planting and at harvest. The exchangeable cations and cation exchange capacity (CEC) were determined by the method described by Thomas (1982). Aluminium and hydrogen content (exchangeable acidity) was determined by titrimetric method after extraction with $1.0 \mathrm{~N} \mathrm{KCl} \mathrm{[21].} \mathrm{Available} \mathrm{phosphorus} \mathrm{was}$ extracted with Bray II extractant as described by Bray and Kurtz [23] and determined colorimeterically using ascorbic acid method [24]. Particle size distribution analysis was done by the hydrometer method [25] and the corresponding textual class determined from the United State Department of Agriculture Soil Texture Triangle. Dry bulk density was determined by the core method [26]. Total porosity values were derived from bulk density data. Saturated hydraulic conductivity (Ksat) was determined [27].

\section{Data analysis}

Data collected was subjected to analysis of variance (ANOVA) test for randomized complete block design as outlined by [28]. Significant means was separated using Fisher's least significant difference (F-LSD) at $5 \%$ probability level. Three simple linear regression analyses was done to derive a model for the estimation of number of nodules per plant versus SSP fertilizer rates (Y1), fresh pod weight per plant at harvest versus single super phosphate (SSP) fertilizer rates (Y2) and soil total nitrogen at harvest versus SSP fertilizer rate (Y3). Statistical analysis was executed using Statistical Software [29].

\section{Results and Discussion}

\section{Pre-planting soil analysis}

The pre-planting analyses of soil properties in both years are presented in the Table 1 . The result indicated that the textural class of the study site is loamy sand. Percentage organic carbon $(0.65 \%)$ and nitrogen $(0.038 \%)$ are low indicating values below critical levels for the 
Citation: Ikenganyia EE, Anikwe MAN, Ngwu OE (2017) Influence of Rhizobacteria Inoculant Application Methods and Phosphate Fertilizer Rates on Dry Matter Accumulation, Yield of Bambara Groundnut [Vigna subterranea (L.) Verdc] and Soil Total Nitrogen Content in a Degraded Ultisol in Southeast Nigeria. Agrotechnology 6: 165. doi: 10.4172/2168-9881.1000165

Page 4 of 7

study area. However, these values were higher in 2016 planting season compared 2015 planting season $(0.65 \%$ and $0.041 \%)$, respectively. As expected, this indicated that the soil had higher values for soil nutrient at the start of the experiment in 2016 when compared to 2015 planting season because of the influence of the legumes planted in the previous season. The soil $\mathrm{pH}$ in $\mathrm{KCl}$ ranged from 5.4 to 6.2 in both years indicating slight acidity according to the rating by Landon (1991). The pre-planting exchangeable cations content and exchangeable acidity of the soil in 2015 were $\left(\mathrm{Mg}^{2+} 0.70, \mathrm{~K}^{+} 0.17, \mathrm{Na}^{+} 0.09, \mathrm{Al}^{3+} 3.27\right.$ and CEC $\left.8.1 \mathrm{cmol} \mathrm{kg}^{-1}\right)$ whereas the values obtained in 2016 were $\left(\mathrm{Mg}^{2+} 0.90, \mathrm{~K}^{+}\right.$ $0.10, \mathrm{Na}^{+} 0.17, \mathrm{Al}^{3+} 3.20$ and CEC $\left.8.10 \mathrm{cmol} \mathrm{kg}^{-1}\right)$.

Effect of rhizobacteria inoculant application methods on the dry matter accumulation, yield of Bambara groundnut and soil total nitrogen content

The data presented in Table 2 shows the main effect of rhizobacteria inoculant application methods on the dry matter accumulation, yield of Bambara groundnut [Vigna subterranea (L.) Verdc.] and soil total nitrogen at harvest in 2015 and 2016 planting seasons. The results from the study showed that soil applied rhizobacteria inoculant increased leaf, stem and root dry weight of Bambara groundnut significantly $(\mathrm{P}<0.05)$ by between $19-25 \%$ when compared with seed applied rhizobacteria

\begin{tabular}{|c|c|c|}
\hline Parameters & 2015 & 2016 \\
\hline \multicolumn{3}{|c|}{ Particle size distribution (\%) } \\
\hline Coarse sand & 46 & 47 \\
\hline Fine sand & 41 & 40 \\
\hline Clay & 5 & 5 \\
\hline Silt & 8 & 8 \\
\hline Textural class & Loamy sand & Loamy sand \\
\hline Bulk density $\left(\mathrm{Mg} \mathrm{m}^{-3}\right)$ & 1.57 & 1.52 \\
\hline Total porosity (\%) & 41 & 43 \\
\hline Saturated hydraulic conductivity $\left(\mathrm{Cm} \mathrm{hr}^{-1}\right)$ & 21.72 & 22 \\
\hline $\mathrm{pH}$ (water) & 6.1 & 6.3 \\
\hline $\mathrm{pH}(\mathrm{KCl})$ & 5.4 & 5.7 \\
\hline Organic carbon (\%) & 0.65 & 0.69 \\
\hline Total nitrogen (\%) & 0.038 & 0.041 \\
\hline Available phosphorus (c mol kg-1) & 7.91 & 8.82 \\
\hline \multicolumn{3}{|c|}{ Exchangeable bases $\left(\mathrm{cmol} \mathrm{kg}^{-1}\right)$} \\
\hline Calcium & 1.2 & 1.6 \\
\hline Magnesium & 0.72 & 0.79 \\
\hline Potassium & 0.17 & 0.16 \\
\hline Sodium & 0.9 & 0.98 \\
\hline \multicolumn{3}{|c|}{ Exchangeable acidity $\left(\mathrm{cmol} \mathrm{kg}^{-1}\right)$} \\
\hline Hydrogen & 2.66 & 2.4 \\
\hline Aluminum & 3.24 & 3.06 \\
\hline Cation exchangeable capacity $\left(\mathrm{cmol} \mathrm{kg}^{-1}\right)$ & 8.1 & 8.9 \\
\hline
\end{tabular}

Table 1: Initial soil characteristics before planting in 2015 and 2016 cropping season. inoculants. Higher plant dry matter accumulation at harvest were found in soil applied rhizobacteria inoculant plots [leaf dry weight was $40.74 \mathrm{~g}$ to $43.81 \mathrm{~g}$ plant, stem dry weight was $30.85 \mathrm{~g}$ to $33.11 \mathrm{~g}$ plant and root dry weight was $8.01 \mathrm{~g}$ to $8.44 \mathrm{~g}$ plant for both seasons] when compared with seed applied rhizobacteria inoculants plots with leaf dry weight of $35.50 \mathrm{~g}$ to $38.81 \mathrm{~g}$ plant, stem dry weight of $24.89 \mathrm{~g}$ to $27.08 \mathrm{~g}$ plant and root dry weight of $6.30 \mathrm{~g}$ to $6.78 \mathrm{~g}$ plant at harvest for both seasons. In this study, bacteria applied by soil inoculation significantly enhanced plant biomass, nodulation, and seed yield of Bambara groundnut to a higher degree than seed applied rhizobacteria. Studies by [30] showed that soil inoculation with rhizobacteria resulted in better crop yields and more efficient colonization than direct inoculation of seeds [31].

This outcome is attributed to the ability of the rhizobacteria to spread quickly in the rhizosphere, convert atmosphere nitrogen $\left(\mathrm{N}_{2}\right)$ into nitrate and ammonia forms of nitrogen needed by plant for growth and development. More so, the application of rhizobacteria inoculant to the soil increased the microbial population of the soil thereby creating a suitable niche for the plant microbe interaction.

Soil applied rhizobacteria inoculant increased number of root nodules, fresh pods of Bambara groundnut and soil total Nitrogen content at 90 days after planting (DAP) significantly $(\mathrm{P}<0.05)$ by $29 \%, 22 \%$ and $48 \%$ respectively when compared with seed applied rhizobacteria inoculants.

Higher number of nodules per plant at eight weeks after planting [52-55] number of fresh pods per plant [9], fresh pod weight per plant [150.00-154.10 g plant] and post-harvest soil Total N [0.18\% to $0.20 \%]$ were found in soil applied rhizobacteria inoculant plots for both seasons when compared with seed applied rhizobacteria inoculants plots with the number of nodules per plant at eight weeks after planting, number of fresh pod at harvest [7] and fresh pod weight at harvest [112.70 g to $117.68 \mathrm{~g}$ plant] and post-harvest soil Total $\mathrm{N}$ [0.09\% to $0.11 \%$ ] for both seasons. The beneficial effect of inoculating the soil with effective rhizobacteria is that it promotes nodulation and yield of leguminous crops. The mechanisms by which rhizobacteria stimulates nodulation is that is promotes the availability of nutrients and phosphate solubilization and production of phytohormones. It is postulated that observed differences between soil and seed inoculation could be that seeds may have released exudates before germination in soil, which favored the growth of other seed-residing microorganisms and outcompeted the inoculated bacteria on the seed coat [31,32]. Nelson (2004) also contended that cells may have been stressed or injured during seed plantation and germination. Seed exudates can consist of many different molecules including sugars, amino acids, organic acids, and phenolic compounds among others, but little is known about the specific response of microorganisms to these. Additionally, various sulphur-containing compounds are produced by seeds and some of these have been found to have anti-microbial effects (Lanzotti 2006), which might reduce the number of inoculated cells.

\begin{tabular}{|c|c|c|c|c|c|c|c|c|c|c|c|c|c|c|}
\hline \multirow[t]{2}{*}{ Methods } & \multicolumn{2}{|c|}{$\begin{array}{l}\text { Leaf dry weight } \\
\quad\left(\text { g plant }^{-1}\right)\end{array}$} & \multicolumn{2}{|c|}{$\begin{array}{l}\text { Stem dry weight } \\
\left.\text { (g plant }^{-1}\right)\end{array}$} & \multicolumn{2}{|c|}{$\begin{array}{l}\text { Root dry weight } \\
\left.\text { (g plant }^{-1}\right)\end{array}$} & \multicolumn{2}{|c|}{$\begin{array}{l}\text { Number of nodules per plant } \\
\text { at eight weeks after planting }\end{array}$} & \multicolumn{2}{|c|}{$\begin{array}{c}\text { Number of fresh } \\
\text { pod }\end{array}$} & \multicolumn{2}{|c|}{$\begin{array}{l}\text { Fresh pod weight } \\
\quad\left(\text { g plant }^{-1}\right)\end{array}$} & \multicolumn{2}{|c|}{$\begin{array}{c}\text { Soil total } \\
\text { nitrogen (\%) }\end{array}$} \\
\hline & 2015 & 2016 & 2015 & 2016 & 2015 & 2016 & 2015 & 2016 & 2015 & 2016 & 2015 & 2016 & 2015 & 2016 \\
\hline Seed applied & 35.5 & 38.81 & 24.89 & 27.08 & 6.3 & 6.78 & 37 & 39 & 7 & 7 & 112.7 & 117.68 & 0.09 & 0.11 \\
\hline Soil applied & 40.74 & 43.81 & 30.85 & 33.11 & 8.01 & 8.44 & 52 & 55 & 9 & 9 & 150 & 154.1 & 0.18 & 0.2 \\
\hline $\begin{array}{c}\mathrm{LSD}_{(0.05)} \text { for any } 2 \\
\text { methods }\end{array}$ & 1.65 & 0.04 & 1.09 & 0.05 & 0.42 & 0.04 & 2.23 & 0.04 & 0.39 & 0.39 & 5.22 & 0.03 & 0.02 & 0.03 \\
\hline
\end{tabular}

$\mathrm{LSD}_{(0.05)}$ - Least significant difference at 0.05 probability level

Table 2: Main effects of Rhizobacteria inoculant application method on dry matter accumulation yield of Bambara groundnut [Vigna subterranea (L.) Verdc.] and soil total nitrogen content at harvest in 2015 and 2016 planting season. 
Citation: Ikenganyia EE, Anikwe MAN, Ngwu OE (2017) Influence of Rhizobacteria Inoculant Application Methods and Phosphate Fertilizer Rates on Dry Matter Accumulation, Yield of Bambara Groundnut [Vigna subterranea (L.) Verdc] and Soil Total Nitrogen Content in a Degraded Ultisol in Southeast Nigeria. Agrotechnology 6: 165. doi: 10.4172/2168-9881.1000165

Page 5 of 7

\section{Effect of phosphate fertilizer rates on the dry matter accumulation, yield of Bambara groundnut and soil total nitrogen content}

Soils fertilized with $75 \mathrm{~kg} \mathrm{P} \mathrm{ha}^{-1}$ produced the highest dry matter (above and below) yield of Bambara groundnut (97.37 g) and this was significantly higher than when $\mathrm{P}$ was applied at $0 \mathrm{~kg} \mathrm{P}^{-1}, 25 \mathrm{~kg} \mathrm{P}$ $\mathrm{ha}^{-1}$ and $50 \mathrm{~kg} \mathrm{P} \mathrm{ha}^{-1}$ by $54 \%, 32 \%$ and $15 \%$ respectively for the two cropping seasons (Table 3). The leaf dry weight, stem dry weight and root dry weight at harvest increased $(\mathrm{P}<0.05)$ with an increasing rate of single super phosphate fertilizer addition to the soil in the order of influence of $51.07 \mathrm{~kg} \mathrm{P} \mathrm{ha}^{-1}<72.05 \mathrm{~kg} \mathrm{P} \mathrm{ha}^{-1}<82.33 \mathrm{~kg} \mathrm{P} \mathrm{ha}^{-1}<97.37 \mathrm{~kg}$ $\mathrm{P} \mathrm{ha}^{-1}$ for plots amended with $0 \mathrm{~kg} \mathrm{P} \mathrm{ha}^{-1}<25 \mathrm{~kg} \mathrm{P} \mathrm{ha}^{-1}<50 \mathrm{~kg} \mathrm{P}$ ha ${ }^{1}<75 \mathrm{~kg} \mathrm{P} \mathrm{ha}^{-1}$ respectively. The increase in dry matter accumulation recorded in this study is due to increased supply of phosphorus (Reedy et al., 2000), which might have accelerated cell division and system development in plants as reported by [32]. [33] Also reported that the application of $60 \mathrm{~kg} \mathrm{P}_{2} \mathrm{O}_{5} \mathrm{ha}^{-1}$ increased dry matter production due to increased respiration and photosynthetic ability. More so, Wabekwa et al. in 2014) reported that dry matter production also increased with increasing phosphorus application.

The result also shows that application of single super phosphate fertilizer at varying rates significantly $(\mathrm{P}<0.05)$ affected the number of fresh pod at harvest, fresh pod weight at harvest and post-harvest soil Total $\mathrm{N}$ for both seasons. Bambara groundnut grown on soils fertilized with $75 \mathrm{~kg} \mathrm{P} \mathrm{ha}{ }^{-1}$ produced the highest number of nodules per plant [60-63], number of fresh pod at harvest [10-11] and fresh pod weight at harvest [158.60 $\mathrm{g}$ to $164.60 \mathrm{~g}$ plant] followed by Bambara groundnut grown on plots which received $50 \mathrm{~kg} \mathrm{P} \mathrm{ha}^{-1}$ that produced $50-54$ nodules per plant, 9 fresh pod at harvest and $146.60 \mathrm{~g}$ to $149.75 \mathrm{~g}$ plant fresh pod weight at harvest whereas plots amended with $25 \mathrm{~kg} \mathrm{P} \mathrm{ha}^{-1}$ produced 40 to 43 nodules per plant, fresh pod at harvest (7) and fresh pod weight at harvest $[127.80 \mathrm{~g}$ to $134.56 \mathrm{~g}$ plant]. The plots that did not receive $\mathrm{P}\left(0 \mathrm{~kg} \mathrm{P} \mathrm{ha}^{-1}\right)$ produced the least number of nodules per plant [2728 ], number of fresh pod at harvest (6) and fresh pod weight at harvest [ $92.30 \mathrm{~g}$ to $94.66 \mathrm{~g}$ plant] respectively when compared with the other SSP fertilizer rates. Phosphorus deficiency is common in most soils in southeastern Nigeria because of problems associated with P fixation. Inadequate $\mathrm{P}$ restricts root growth, the process of photosynthesis, translocation of sugars, and other such functions, which directly or indirectly influence nitrogen fixation by legume plants $[34,35]$.

The significant response to phosphorus fertilizer application observed in terms of nodulation count and yield may be attributed to the fact that phosphorus stimulates root and plant growth, initiates nodule formation as well as influences the general efficiency of the rhizobiumlegume symbiosis, thereby optimizes the biological nitrogen fixation (BNF) system of legume. This result agreed with the findings of [36,37].
Post-harvest soil total nitrogen content was significantly $(\mathrm{P}<0.05)$ influenced by the SSP fertilizer rates. These results show that, at the different SSP rates, post-harvest soil, total nitrogen concentration increased by a magnitude of between $79 \%$ to $81 \%$ in the two cropping seasons. SSP fertilizer rate increases $\left(0 \mathrm{~kg} \mathrm{P} \mathrm{ha}^{-1}<25 \mathrm{~kg} \mathrm{P}^{-1}<50 \mathrm{~kg} \mathrm{P}\right.$ $\left.\mathrm{ha}^{-1}<75 \mathrm{~kg} \mathrm{P} \mathrm{ha}^{-1}\right)$ resulted in corresponding post-harvest total soil total nitrogen levels $(0.04 \%<0.09 \%<0.15 \%<0.22 \%)$ respectively for the two seasons of the study. Considering that some rhizobacteria possess ability of phosphate solubilization, they could be useful in crop production improvement by increasing $\mathrm{P}$ content in the soil and enhancing nodulation and $\mathrm{N}$ fixation in legumes. According to [38] the inoculation of plants with rhizobacteria can increase native population through various mechanisms that convert insoluble inorganic and organic soil $\mathrm{P}$ into plant available forms and therefore improve plant nutrition.

\section{Interaction effects of bacterial inoculant application method and phosphate fertilizer rates on the dry matter accumulation, yield of Bambara groundnut and soil total nitrogen content}

The data presented in Table 4 show the interaction effects rhizobacteria inoculant application methods and phosphate fertilizer rates on the dry matter accumulation, yield of Bambara groundnut [Vigna subterranea (L.) Verdc.] and soil total nitrogen at harvest in 2015 and 2016 cropping seasons. At harvest, soil applied rhizobacteria inoculant plots which received $75 \mathrm{~kg} \mathrm{P} \mathrm{ha}^{-1}$ had significantly $(\mathrm{P}<0.05)$ the highest leaf dry weight [53.07-59.11 g plant), stem dry weight [40.73g to $44.17 \mathrm{~g}$ plant] and root dry weight [9.83-10.23 g plant] respectively in the two seasons of study. The results showed that leaf, stem and root dry weight increased by between $49 \%$ to $58 \%$ when compared with seed applied rhizobacteria plots that did not receive SSP fertilizers which gave the lowest dry matter yield of Bambara groundnuts in the two seasons.

Results also show that soil applied rhizobacteria inoculant plots which received $75 \mathrm{~kg} \mathrm{P} \mathrm{ha}^{-1}$ had significantly $(\mathrm{P}<0.05)$ higher number of nodules per plant at eight weeks after planting higher number of fresh pod at harvest [12], higher fresh pod weight at harvest [175.90g to $180.90 \mathrm{~g}$ plant] and higher post-harvest soil total $\mathrm{N}$ content $[0.27 \%$ to $0.29 \%$ ] respectively in the two seasons of study. These results showed that in soil applied rhizobacteria plots, the number of nodules per plant, number of fresh pod at harvest, fresh pod weight at harvest and post-harvest soil total $\mathrm{N}$ content at $75 \mathrm{~kg} \mathrm{P} \mathrm{ha}{ }^{-1}$ increased by $66 \%, 58 \%, 52 \%$ and $76 \%$ respectively when compared with their corresponding seed applied rhizobacteria inoculant plots that did not receive SSP fertilizers in the two seasons.

\section{Relationship between number of nodules, fresh pod weight, total soil nitrogen and phosphate fertilizer rates}

The results in Table 5 shows that there is a significant $(\mathrm{P}<0.05)$

\begin{tabular}{|c|c|c|c|c|c|c|c|c|c|c|c|c|c|c|}
\hline \multirow{2}{*}{$\begin{array}{c}\text { SSP } \\
\text { fertilizer } \\
\text { rates }(k g ~ P \\
\text { ha-1 }^{-1} \\
\end{array}$} & \multicolumn{2}{|c|}{$\begin{array}{l}\text { Leaf dry weight (g } \\
\quad \text { plant }^{-1} \text { ) }\end{array}$} & \multicolumn{2}{|c|}{$\begin{array}{l}\text { Stem dry weight (g } \\
\text { plant }^{-1} \text { ) }\end{array}$} & \multicolumn{2}{|c|}{$\begin{array}{l}\text { Root dry weight (g } \\
\text { plant }^{-1} \text { ) }\end{array}$} & \multicolumn{2}{|c|}{$\begin{array}{c}\text { Number of nodules } \\
\text { per plant at eight } \\
\text { weeks after planting }\end{array}$} & \multicolumn{2}{|c|}{$\begin{array}{c}\text { Number of fresh } \\
\text { pod per plant }\end{array}$} & \multicolumn{2}{|c|}{$\begin{array}{l}\text { Fresh pod weight (g } \\
\text { plant }^{-1} \text { ) }\end{array}$} & \multicolumn{2}{|c|}{$\begin{array}{c}\text { Soil total nitrogen } \\
(\%)\end{array}$} \\
\hline & 2015 & 2016 & 2015 & 2016 & 2015 & 2016 & 2015 & 2016 & 2015 & 2016 & 2015 & 2016 & 2015 & 2016 \\
\hline 0 & 27.53 & 29.72 & 18.15 & 19.67 & 4.83 & 5.23 & 27 & 29 & 6 & 6 & 92.3 & 94.66 & 0.04 & 0.04 \\
\hline 25 & 35.33 & 39.46 & 25.95 & 28.13 & 7.37 & 7.86 & 41 & 43 & 7 & 7 & 127.8 & 134.56 & 0.07 & 0.09 \\
\hline 50 & 41.58 & 43.12 & 30.8 & 33.2 & 7.78 & 8.17 & 50 & 54 & 9 & 9 & 146.6 & 149.75 & 0.12 & 0.15 \\
\hline 75 & 48.03 & 52.94 & 36.58 & 39.39 & 8.63 & 9.17 & 60 & 63 & 10 & 11 & 158.6 & 164.6 & 0.19 & 0.22 \\
\hline $\begin{array}{l}\mathrm{LSD}_{(0.05)} \text { for } \\
\text { any } 2 \text { rates }\end{array}$ & 2.33 & 0.06 & 1.54 & 0.06 & 0.59 & 0.06 & 3.15 & 0.05 & 0.55 & 0.06 & 7.38 & 0.05 & 0.03 & 0.04 \\
\hline & & & & LSD & - Leas & nificant & differenc & .05 prob & bility leve & & & & & \\
\hline
\end{tabular}

Table 3: Main effects of phosphate fertilizer rates on dry matter accumulation yield of Bambara groundnut [Vigna subterranea (L.) Verdc.] and soil total nitrogen content at harvest in 2015 and 2016 planting season. 
Citation: Ikenganyia EE, Anikwe MAN, Ngwu OE (2017) Influence of Rhizobacteria Inoculant Application Methods and Phosphate Fertilizer Rates on Dry Matter Accumulation, Yield of Bambara Groundnut [Vigna subterranea (L.) Verdc] and Soil Total Nitrogen Content in a Degraded Ultisol in Southeast Nigeria. Agrotechnology 6: 165. doi: 10.4172/2168-9881.1000165

Page 6 of 7

\begin{tabular}{|c|c|c|c|c|c|c|c|c|c|c|c|c|c|c|}
\hline \multirow[t]{2}{*}{$\begin{array}{l}\text { Method } x \text { rate }(\mathbf{k g} \\
\left.\quad \mathbf{P ~ h a}^{-1}\right)\end{array}$} & \multicolumn{2}{|c|}{$\begin{array}{l}\text { Leaf dry weight (g } \\
\left.\text { plant }^{-1}\right)\end{array}$} & \multicolumn{2}{|c|}{$\begin{array}{l}\text { Stem dry weight } \\
\left(\text { g plant }^{-1}\right)\end{array}$} & \multicolumn{2}{|c|}{$\begin{array}{l}\text { Root dry weight } \\
\quad\left(\text { g plant }^{-1}\right)\end{array}$} & \multicolumn{2}{|c|}{$\begin{array}{l}\text { Number of nodules } \\
\text { per plant at eight } \\
\text { weeks after planting }\end{array}$} & \multicolumn{2}{|c|}{$\begin{array}{l}\text { Number of } \\
\text { fresh pod per } \\
\text { plant }\end{array}$} & \multicolumn{2}{|c|}{$\begin{array}{l}\text { Fresh pod weight } \\
\quad\left(\text { g plant }^{-1}\right)\end{array}$} & \multicolumn{2}{|c|}{$\begin{array}{c}\text { Soil total nitrogen } \\
(\%)\end{array}$} \\
\hline & 2015 & 2016 & 2015 & 2016 & 2015 & 2016 & 2015 & 2016 & 2015 & 2016 & 2015 & 2016 & 2015 & 2016 \\
\hline Seed applied $\times 0$ & 27.17 & 29.44 & 17.1 & 19.22 & 4.53 & 5 & 25 & 27 & 5 & 5 & 84.4 & 86.12 & 0.04 & 0.03 \\
\hline Soil applied $\times 0$ & 27.9 & 30 & 19.2 & 20.11 & 5.13 & 5.46 & 28 & 30 & 7 & 7 & 100.3 & 103.2 & 0.08 & 0.08 \\
\hline Seed applied $\times 25$ & 32.87 & 38.92 & 22.87 & 24.14 & 6.33 & 6.79 & 37 & 39 & 7 & 7 & 100 & 109.11 & 0.09 & 0.12 \\
\hline Soil applied × 25 & 37.8 & 40 & 29.87 & 32.11 & 8.4 & 8.92 & 45 & 47 & 7 & 7 & 155.7 & 160 & 0.14 & 0.15 \\
\hline Seed applied $\times 50$ & 38.97 & 40.11 & 27.17 & 30.33 & 6.9 & 7.2 & 40 & 44 & 8 & 8 & 125 & 127.2 & 0.17 & 0.18 \\
\hline Soil applied × $50 \mathrm{~kg}$ & 44.2 & 46.12 & 34.43 & 36.06 & 8.67 & 9.14 & 61 & 64 & 9 & 10 & 168.2 & 172.3 & 0.2 & 0.23 \\
\hline Seed applied $\times 75 \mathrm{~kg}$ & 43 & 46.77 & 32.43 & 34.61 & 7.43 & 8.11 & 44 & 46 & 9 & 9 & 141.3 & 148.3 & 0.23 & 0.24 \\
\hline Soil applied $\times 75 \mathrm{~kg}$ & 53.07 & 59.11 & 40.73 & 44.17 & 9.83 & 10.23 & 76 & 80 & 12 & 12 & 175.9 & 180.9 & 0.27 & 0.29 \\
\hline $\begin{array}{l}\mathrm{LSD}_{\text {(0.0.5) }} \text { for any } 2 \\
\text { methods } \times \text { rates }\end{array}$ & 3.3 & 0.08 & 2.18 & 0.09 & 0.83 & 0.09 & 4.45 & 0.08 & 0.78 & 0.08 & 10.44 & 0.07 & 0.02 & 0.03 \\
\hline
\end{tabular}

$\mathrm{LSD}_{(0.05)}$ - Least significant difference at 0.05 probability level

Table 4: Interaction effects of Rhizobacteria inoculant application method and phosphate fertilizer rates on dry matter accumulation yield of Bambara groundnut [Vigna subterranea (L.) Verdc.] and soil total nitrogen content at harvest in 2015 and 2016 planting season.

\begin{tabular}{|c|c|c|c|c|}
\hline Predictors variable (Y) & Regression model & $\mathbf{R}$ & $\mathbf{R}^{\mathbf{2}}$ & Standard error of estimate \\
\hline Y1-Number of nodules per plant & Y1=28+0.44P & $0.774^{*}$ & $0.599^{*}$ & 10.514 \\
\hline Y2-Fresh pod weight per plant & Y 2=98.1+0.87P & $0.750^{*}$ & $0.563^{*}$ & 24 \\
\hline Y3-Soil total nitrogen & Y 3=22.0-355.30P & $0.990^{*}$ & $0.981^{*}$ & 22.39 \\
\hline
\end{tabular}

$\mathrm{Y} 1, \mathrm{Y} 2$, and $\mathrm{Y} 3$-Predictors variables, $\mathrm{P}$-Explanatory variables (phosphate fertilizer rates), "-significant at $\mathrm{P}<0.05, \mathrm{n}$-number of observations, $\mathrm{R}$-correlation coefficient, $\mathrm{R}^{2}$ correlation of determination

Table 5: Relationship between number of nodules, fresh pod weight, soil total nitrogen and phosphate fertilizer rates.

positive linear relationship between number of nodules per plant $\left(\mathrm{R}^{2}=0.60^{*}\right)$, fresh pod weight per plant $\left(\mathrm{R}^{2}=0.56^{*}\right)$, total soil nitrogen

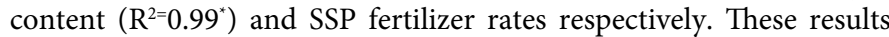
indicate that a better relationship was established using SSP fertilizer rate in improving the post-harvest soil total nitrogen concentration, fresh pod weight per plant and number of nodules per plant. Various workers $[32,39,40]$ noted that phosphorous deficiency has been shown to affect symbiosis by decreasing the supply of photosynthates to the nodule, which reduces the rate of bacterial growth and the total population of legume-nodulating microorganisms [41-46]. Reported that enhancement in nodule number, nodular mass due to inoculation might lead to the expansion in root length and mass, thus more number of active sites for nodulation by the rhizobial strains.

\section{Conclusions}

Agronomic practices like methods of delivery of plant growth promoting bacteria and application of phosphate fertilizer at the appropriate rates can have profound influence on plant growth. Soil inoculation of Rhizobium and supplemental application of $75 \mathrm{~kg} \mathrm{ha}^{-1}$ SSP enhanced the shoot, root dry weights, nodulation, yield and postharvest soil total $\mathrm{N}$ content of Bambara groundnut as compared to seed inoculation of Rhizobium and sub-optimal rates of $\mathrm{P}$ fertilizer. This is due to direct and indirect enhancement of plant growth by a variety of mechanisms such as production of growth promoting substance and solubilization of minerals such as $\mathrm{P}$ in the soil.

A combination of soil inoculation and appropriate rates of $\mathrm{P}$ fertilizer increased growth and yield, compared to seed inoculation, probably due to the synergistic effect of balanced nutrition, and improved absorption of nitrogen, phosphorus, and other mineral nutrients. Phosphorous availability increased the number and size of nodules and the amount of nitrogen assimilated per unit weight of nodules, increasing the percent and total amount of nitrogen in the harvested portion of the host legume and improving the density of Rhizobia bacteria in the soil surrounding the root. The positive effect of combined soil inoculation of rhizobacteria with optimum rate of phosphorus fertilization resulted in a general improvement in dry matter yield, number of nodules, and increased post-harvest soil total $\mathrm{N}$ content.

\section{References}

1. Swanevelder CJ (1998) Bambara -Food for Africa

2. FAO (2001) A Global Mapping System for Bambara Groundnut Production FAO, Rome.

3. Azam-ali SN, Sesay A, Karikari S, Massawe FJ, Aguilar-manjarrez J, et al (2001) Assessing the potential of an underutilized crop: A case study using bambara groundnut. Explor Agric 37: 433-472.

4. Mwale SS, Azam-ali SN, Massawe FJ (2007) Growth and development of bambara groundnut (Vigna subterranea) in response to soil moisture I. Dry matter and yield. Eur J Agron 26: 345-353.

5. Hubbell DH, Kidder G (2009) Biological Nitrogen Fixation. University of Florida, IFAS Extension Publication, SL 16:1-4.

6. Egbe OM, Kalu BA, Idoga S (2009) Contribution of common food legumes to the fertility status of sandy soils of the moist savanna woodlands of Nigeria. Rep Opinion J 1: 45-62.

7. Alhassan GA, Kalu BA, Egbe OM (2012) Influence of planting densities on the performance of intercropped Bambara groundnut with cowpea in Makurdi, Benue state, Nigeria. Int J Dev Sustainability 1: 860-879.

8. Yakubu H, Kwari JD, Sandabe MK (2010) Effect of phosphorus fertilizer on nitrogen fixation by some grain legumes varieties in Sudano-Sahelian zone of North -Eastern Nigeria. Niger J Basic App Sci 18: 44-49.

9. Goli AE (1997) Conservation and Improvement of Bambara groundnut (Vigna subterranea [L.] Verdc). In: Heller J, F Begeman, J Mushonga (eds) Bibliographical Review. Proceedings of an International Workshop held at Harare, Zimbabwe, IPK/IPGRI: 4-10.

10. Karikari SK, Wigglesworth DJ, Kwerepe BC, Balole TV, Sebolai B, et al (1997) Country Reports: Botwana. In: Heller J, Begeman F, Mushonga J (eds) Conservation and improvement of Bambara groundnut (Vigna subterranea [L.] Verdc.), Proceedings of an International Workshops held at Harare, Zimbarbwe. IPK/IPGRI 11-19.

11. Massawe FJ, Dickson M, Roberts JA, Azam-Ali SN (2002) Genetic diversity in Bambara groundnut (Vigna subterranean [L.] Verdc.), land races revealed by AFLP markers. Published on NRC Research Press Website http//:www. genome.nrc.ca, Canada. 
Citation: Ikenganyia EE, Anikwe MAN, Ngwu OE (2017) Influence of Rhizobacteria Inoculant Application Methods and Phosphate Fertilizer Rates on Dry Matter Accumulation, Yield of Bambara Groundnut [Vigna subterranea (L.) Verdc] and Soil Total Nitrogen Content in a Degraded Ultisol in Southeast Nigeria. Agrotechnology 6: 165. doi: 10.4172/2168-9881.1000165

12. Federal Ministry of Agriculture and Rural Development (FMARD) (2002) Fertilizer use and Management Practice for Crops in Nigeria: In: Aduayi EA, Chude VO, Adebusayi BA, Olayiwola GO (eds). Federal Fertilizer Department, Abuja. p: $1-88$

13. Anikwe MAN (2006) Soil quality Assessment and Monitoring: A review of current research efforts. New generation books, New Generation Ventures Ltd, Enugu, Southeast Nigeria. p: 208

14. Bhattacharyya PN, Jha DK (2012) Plant growth-promoting rhizobacteria (PGPR): Emergence in agriculture. World J Microbiol Biotechnol 28: 13271350.

15. Sivasakhti S, Usharani G, Saranraj P (2014) Biocontrol potentiality of plant growth promoting bacteria (PGPR)- Pseudomonas fluorescence and Bacillus subtilis: A review. African J Agric Res 9: 1265-1277.

16. Maheshwari DK, Dubey RC, Aeron A, Kumar B, Kumar S, et al. (2012) Integrated approach for disease management and growth enhancement of Sesamum indicum L. utilizing Azotobacter chroococcum TRA2 and chemical fertilizer. World J Microbiol Biotechnol 28: 3015-3024

17. O'Callaghan $M$ (2016) Microbial inoculation of seed for improved crop performance: Issues and opportunities. App Microbiol Biotechnol 100: 5729-5746.

18. Agba OA, Ikenganyia EE, Asiegbu JE (2016) Responses of Mucuna flagellipes to Phosphorus Fertilizer Rates in an Ultisol. Int J Plant Soil Sci 9: 1-9

19. Anikwe MAN, Ikenganyia EE, Egbonimale J, Oputah C (2017) Assessment of some tropical plants for use in the phytoremediation of petroleum contaminated soil: Effects of remediation on soil physical and chemical properties. Int J Plant Soil Sci 14: 1-9.

20. Anikwe MAN, Agu JC, Ikenganyia EE (2016) Agronomic evaluation of four exotic tropical varieties of watermelon (Citrullus lanatus L.) in two agroenvironments in Nigeria. Int J Plant Soil Sci 10: 1-10.

21. McLean EO (1982) Soil pH and lime requirements. In: Page AL. (ed) Methods of Soil Analysis, Part 2. Chemical and Microbial Properties, $2^{\text {nd }}$ edn. Agronomy Series no. 9 Madison, WI, USA, ASA, SSSA.

22. Bremner JM, Mulvaaney CS (1982) Total nitrogen. In: Page AL. (ed) Methods of Soil Analysis, Part 2. Chemical and Microbial Properties, $2^{\text {nd }}$ edn. Agronomy Series no. 9 Madison, WI, USA, ASA, SSSA.

23. Bray RH, Kurtz LT (1945) Determination of Total, Organic and Available Forms of Phosphorus in Soils. Soil Sci 59: 39-46.

24. Murphy J, Riley JP (1962) A Modified Single Solution Method for determination of phosphate in natural waters. Anal Chem Acta 27: 31-36.

25. Gee GW, Bauder D (2002) Particle size analysis. In: Dane JH, Topp GC (eds). Methods of Soil Analysis. Part 4, Physical methods. Soil Sci Soc Am. 5: 255-293.

26. Grossman RB, Reinsch TG (2002) Bulk density and linear extensibility. In: Methods of soil analysis. Part 4. Physical methods'. Soil Science Society of America Book Series No. 5. JH Dane, GC Topp (eds). pp: 201-228. (ASA and SSSA: Madison, WI)

27. Klute A, Dirksen C (1986) Hydraulic conductivity and diffusivity: Laboratory methods. Methods Soil Anal: Part1-Phys Mineral Methods (methods of soil an.1) 687-734

28. Gomes KA, Gomes AA (1984) Statistical producers for Agricultural Research. $2^{\text {nd }}$ edn. John Wiley and Sons. Inc. New York, USA

29. GENSTAT (2007) GENSTAT Release 7.2DE, Discovery Edition 3, Lawes Agricultural Trust, Rothamsted Experimental station.

30. Schiffmann J, Alper Y (1968) Inoculation of peanuts by application of rhizobium suspension into the planting furrows. Exp Agric 4: 219-226
31. Hofte M, Mergeay M, Verstraete W (1990) Marking the rhizopseudomonas strain 7NSK2 with a Mud (lac) element for ecological studies. App Environ Microbiol 56: 1046-1052.

32. Afzal M, Yousaf S, Reichenauer TG, Sessitsch A (2012) The inoculation method affects colonization and performance of bacterial inoculant strains in the phytoremediation of soil contaminated with diesel oil. Int J Phytoremediat 14: $35-47$.

33. Sturz AV, Christie BR (1996) Endophytic bacteria of red clover as agents of allelopathic clover-maize syndromes. Soil Biol Biochem. 28: 583-588.

34. Muhammad AM, Malik MA, Saleem MF (2007) Impact of integration of crop manuring and nitrogen on growth, yield and quality of spring planted sunflower (Helianthus annuus L.). Pak J Botany 39: 449.

35. Tilde AU (1996) Effects of nitrogen and phosphorus rates on growth and yield of sunflower. Unpublished Thesis, Ahmadu Bello University, Zaria.

36. Collavino MM, Sansberro PA, Mroginski LA, Aguilar OM (2010) Comparison of in vitro solubilization activity of diverse phosphate-solubilizing bacteria native to acid soil and their ability to promote Phaseolus vulgaris growth. Biol Fert soils 46: 727-738.

37. Olivera M, Tejera N, Iribarne C, Ocana A, Lluch C (2004) Growth, nitrogen fixation and ammonium assimilation in common bean (Phaseolus vulgaris) Effect of phosphorus. Physiol Plant 121: 498-505.

38. Norman MTJ, Perarson CJ, Seales PGE (1995) The Ecology of Tropical Food Crop. Cambridge University Press, Cambridge, p: 65.

39. Ankomah AB, Zapata F, Hardarson G, Danso SK (1996) Yield, nodulation, and N2 fixation by cowpea cultivars at different phosphorus levels. Biol fert soils 22. $10-15$

40. Singh JS (2013) Plant growth promoting rhizobacteria. Potential microbes for sustainable agriculture. Resonance 18: 275-281.

41. Moreira FMS, Carvalho TS, Siqueira JO (2010) Effect of fertilizers, lime, and inoculation with rhizobia and mycorrhizal fungi on the growth of four leguminous tree species in a low-fertility soil. Biol Fertil Soils 46: 771-779.

42. Sa ALB, Dias ACF, Teixeiria MA, Vieira RF (2012) "Contribution of N2 fixation for the world agriculture," in Bacteria in Agrobiology: Plant Probiotics, Maheshwari DK (eds). Berlin: Springer-Verlag, pp: 33-42.

43. Stajkovic O, Delic D, Josic D, Kuzmanovic D, Rasulic N, et al. (2011) Improvement of common bean growth by co-inoculation with Rhizobium and plant growth-promoting bacteria. Rom Biotechnol Lett 16: 5919-5926.

44. Page JR, Miller RH, Keeney DR, Baker DE, Roscoe Ellis JR, et al. (1982) Methods Soil Analysis 2. Chemical and Microbiology Properties, $2^{\text {nd }}$ edn. Madison, Wisconsin, U.S.A, p:1159

45. Rhoades JD (1982) Cation exchange capacity. In: Page AL, Miller RH, Keeney DR (eds). Methods of soil analysis, Part 2: Chemical methods. Agronomy Monograph no. 9, American Society of Agronomy Madison, Wisconsin, USA.

46. Verma JP, Yadav J, Tiwari KN (2012) Enhancement of nodulation and yield of chickpea by co-inoculation of indigenous mesorhizobium spp. and Plant Growth-Promoting Rhizobacteria in Eastern Uttar Pradesh. Commun Soil Sci Plant Anal 43: 605-621. 